\title{
Primary yolk sac tumor of the retroperitoneal region
}

\author{
Elli Murat ${ }^{1}$, Ayhan Dağdemir ${ }^{1}$, Meltem Ceyhan Bilgici², Yurdanur Süllü ${ }^{3}$
}

'Department of Pediatric Oncology, Medical Faculty, Ondokuz Mayis University, Samsun, Turkey ${ }^{2}$ Department of Pediatric Radiology, Medical Faculty, Ondokuz Mayis University, Samsun, Turkey ${ }^{3}$ Department of Pathology, Medical Faculty, Ondokuz Mayis University, Samsun, Turkey

Germ cell tumors (GCTs) are a group of tumors showing variations in clinical presentation and histopathological and biological characteristics [1, 2]. The GCTs are neoplasms that develop from primordial germ cells of the human embryo, which are normally destined to produce sperm or ova. Primordial germ cells appear to originate in the yolk sac endoderm and migrate around the hindgut to the genital ridge on the posterior abdominal wall where they become part of the developing gonad. Primary extragonadal germ cell tumors (EGCTs) are extremely rare and account for only a small percentage, $1 \%$ to $4 \%$, of all germ cell tumors. Extragonadal yolk sac tumors (YSTs) are very rare. Typically they are found in the midline. The most common extragonadal sites are sacrococcygeal, mediastinal, intracranial, and retroperitoneal [2, 3].

Primary retroperitoneal EGCTs are rarely encountered neoplasms. Also, primary YST of the retroperitoneal region is an extremely rare neoplasm in childhood. Here, we report a primary retroperitoneal yolk sac tumor with liver metastases, treated with chemotherapy without surgery, in a 28-month-old boy.

A 28-month-old boy presented with a week history of increasing abdominal swelling and abdominal pain. Physical examination showed an enlarged abdomen, and the liver edge was palpable $7-8 \mathrm{~cm}$ below the right costal margin. Hematological tests were normal. On biochemical analysis, AST and ALT were above two times the normal level, serum $\alpha$-fetoprotein (AFP) was $80,000 \mathrm{ng} / \mathrm{ml}$ (normal is $0.6-7.9 \mathrm{ng} / \mathrm{ml}$ ), lactate dehydrogenase was $578 \mathrm{IU} / \mathrm{l}$ (normal is 100-300 IU/l), and the human chorionic gonadotropin level was $0.5 \mathrm{mIU} / \mathrm{ml}$ (normal is $0-5 \mathrm{mIU} /$ $\mathrm{ml}$ ). Serological studies were negative for viral hepatitis. Ultrasound revealed massive enlargement of the liver with multiple masses in both lobes. Contrast-enhanced magnetic resonance imaging (MRI) demonstrated that the liver was enlarged (17 cm diameter vertically) and had multiple solid lesions with a maximum size of $42 \mathrm{~mm} \times$ $37 \mathrm{~mm}$ diameter, some of them having a lobular margin on T1- and T2-weighted images with decreased and high signal intensity, respectively. There was a heterogeneous contrast-enhanced solid lesion with diameter of $106 \mathrm{~mm}$ $\times 82 \mathrm{~mm} \times 55 \mathrm{~mm}$ between the hilus of the liver and the left adrenal gland. In addition, the mass was surrounding the celiac and superior mesenteric arteries, and there was compression of the inferior vena cava and displacement of the pancreas anteriorly with an undistinguishable margin with the pancreas on T1- and T2-weighted images (Fig. 1). Thoracic computed tomography (CT) was normal.

An open liver biopsy was performed with initial diagnosis of an atypical hepatoblastoma. The pathological diagnosis was yolk sac tumor of the liver (Fig. 2A and B). Excisional surgical treatment of the tumor could not be applied due to the disseminated disease and bleeding of the tumor. He was treated with 6 courses of the BEP (bleomycin, etoposide, cisplatin) regimen. After 4 cycles of BEP, the size of the masses significantly declined and AFP levels fell to within the normal range. Two years after completion of chemotherapy, he remains clinically well with normal growth and development. There is no evidence of recurrence of tumor by radiologic evaluation and his serum AFP level remains in the normal range.

Malignant germ cell tumors account for approximately $2-3 \%$ of cancer cases in children and adolescents younger than 15 years [1]. Primary EGCTs are rare and have distinct clinicopathologic features. They account for $2-5 \%$ of all germ cell malignancies [4-6]. More than half of these tumors occur at extragonadal sites such as the ovaries (26\%), the coccygeal region (24\%), the testes (18\%) and

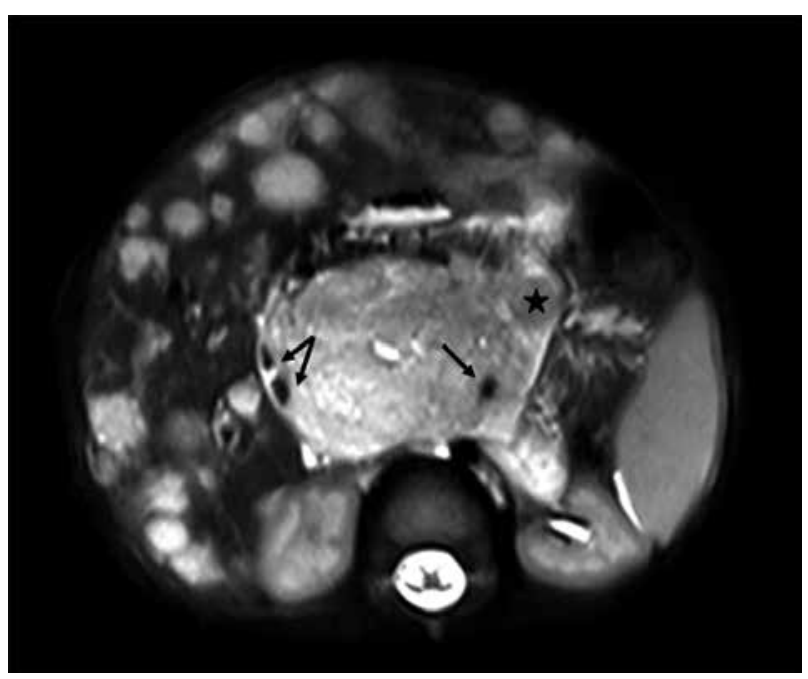

Fig. 1. Multiple solid lesions compatible with metastasis located from prevertebral area to liver hilus and posterior pancreatic compartment. Solid lesions made pancreas (black asterisks) springy anteriorly and laterally. Vascular structures (black arrows) were surrounded by solid lesions. Hyperintense heterogeneous masses with smooth margin also located in left surrenal and liver parenchyma 

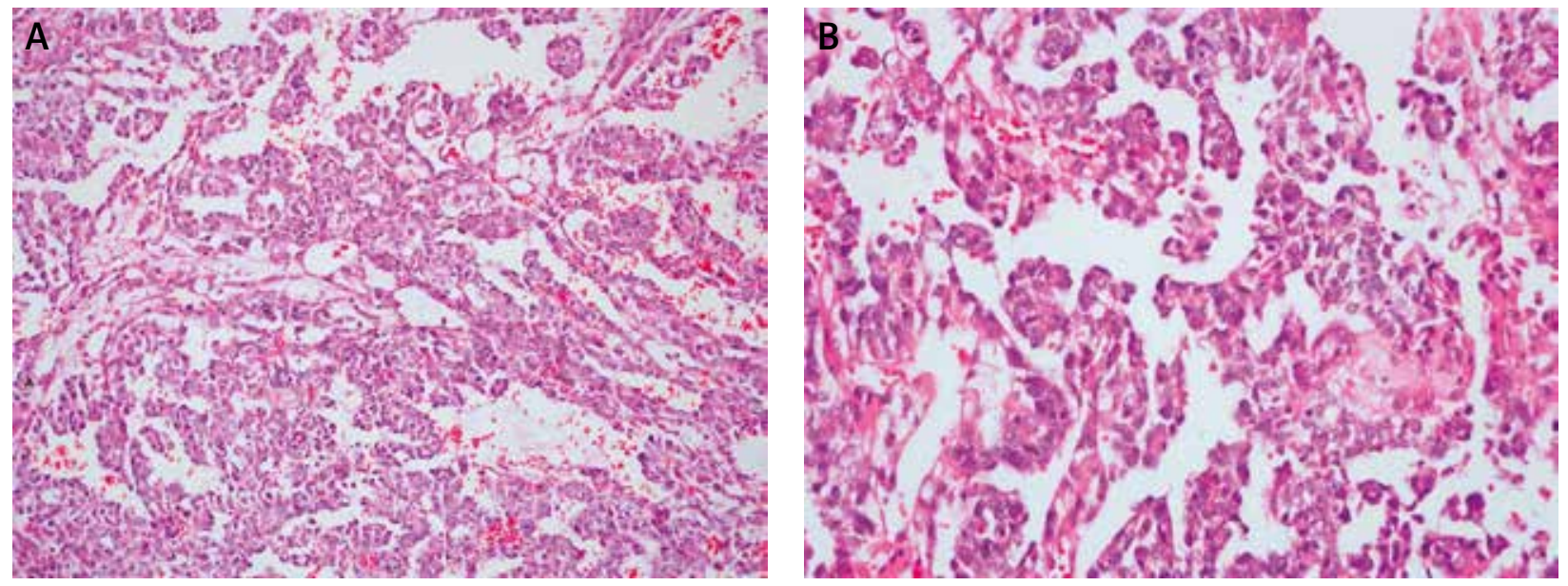

Fig. 2. Medium sized polygonal tumor cells with clear cytoplasm, prominent nuclei in solid and glandular pattern. A) H\&E, magnification $200 \times$; B) $H \& E$, magnification $400 x$

the brain (18\%) as the primary sites. Other extragonadal sites are the mediastinum (4\%), the retroperitoneum (4\%) and the vagina $(2 \%)[2,3]$. Yolk sac tumor, also known as endodermal sinus tumor, is the most common pure malignant germ cell tumor in young children. These neoplasms occur most commonly in the pelvis or testes but can occur in other locations. The most common sites of YSTs are gender specific and gonadal, namely testis in $42.6 \%$ and ovary in $32.6 \%$, and the remaining $24.7 \%$ are extragonadal [7]. Although pelvic and/or retroperitoneal extension of a sacrococcygeal tumor is not unusual, an exclusively retroperitoneal or abdominal location is uncommon, comprising less than $5 \%$ of all extragonadal GCTs. The distribution of extragonadal tumors differs in males and females. Yolk sac tumors originating in the retroperitoneum occur more frequently in males (86\%) than in females (14\%) [3].

Retroperitoneal tumors form an important group of neoplasms in infancy and childhood. The most common retroperitoneal tumors in the pediatric population are neuroblastoma, Wilms tumor and teratomas [8, 9]. Retroperitoneal teratomas occur outside the pelvis, often in a suprarenal location and more often on the left side than on the right. It has been reported that most of the tumors occur in children younger than 5 years [10].

Primary retroperitoneal extragonadal germ cell tumors are rarely encountered neoplasms (1-5\% of all germ cell tumors) without an apparent gonadal primary lesion. The majority of retroperitoneal germ cell tumors in male patients represent a metastasis of a testicular primary lesion [11-14]. Primary YSTs of retroperitoneal GCTs are extremely rare in childhood. A few cases have been reported in the literature. Agarwall et al. [15] reported two cases of retroperitoneal YST in childhood; one of them was pure YST in a two-year old girl. Hirayama et al. [16] reported a case of a two-year-old boy who presented with a huge YST with retroperitoneal lymph node metastases that originated in the left intra-abdominal undescended testis. A case of an extragonadal YST was reported by Lev et al. [17]; it arose as an abdominal mass in the mesentery of the small bowel. Lack et al. [18] reported 11 children (10 female, 1 male) who had been treated for an extragonadal germ cell tumor arising in the retroperitoneum. There were eight teratomas (5 mature, 3 immature), two endodermal sinus tumors and the remaining tumor had a mixture of both components. The cases of YST were seen in two girls of 11 and 18 months old, and one of them had liver metastases and died of the disease. The gonads should be screened before diagnosing a germ cell tumor as being primary in the retroperitoneum, because metastases from an occult testicular tumor can present as a primary retroperitoneal tumor [19]. All of these cases were treated with surgery and chemotherapy. Our case was treated with chemotherapy without surgery.

In this paper, we have reported a case of pediatric primary extragonadal YST of the retroperitoneal region with liver metastases. This is the second case in the literature. On the other hand, he responded very well to chemotherapy only despite liver metastasis. Although YST is one of the poor prognosis cancers in childhood, chemotherapy may be the only curative treatment for these cases. So, before aggressive surgery, a chance may be given to chemotherapy, as in our case.

\section{References}

1. Miller RW, Dalager NA. U.S. Childhood cancer deaths by cell types (1960-1968). J Pediatr 1974; 85: 644-50.

2. Göbel U, Schneider DT, Calaminus G, Haas RJ, Schmidt P, Harms D. Germ-cell tumors in childhood and adolescence. Ann Oncol 2000; 11: 263-71.

3. Hsu YJ, Pai L, Chen YC, Ho CL, Kao WY, Chao TY. Extragonadal germ cell tumors in Taiwan: an analysis of treatment results of $59 \mathrm{pa}-$ tients. Cancer 2002; 95: 766-74.

4. Bokemeyer C, Nichols CR, Droz JP, Schmoll HJ, et al. Extragonadal germ cell tumors of the mediastinum and retroperitoneum: results from an international analysis. J Clin Oncol. 2002; 20: 1864-73.

5. Schneider DT, Calaminus G, Koch S, Teske C, Schmidt P, Haas RJ, Harms D, Göbel U. Epidemiologic analysis of 1442 children and adolescents registered in the German germ cell tumor protocols. Pediatr Blood Cancer 2004; 42: 169-75.

6. Iczkowski KA, Butler SL, Shanks JH, et al. Trials of new germcell immunohistochemical stains in 93 extragonadal and metastatic germ cell tumors. Hum Pathol 2008; 39: 275-81.

7. Shah JP, Kumar S, Bryant CS, Ali-Fehmi R, Malone JM Jr, Deppe G, Morris RT. A population-based analysis of 788 cases of yolk sac tumors: A comparison of males and females. Int J Cancer 2008; 123: 2671-5. 
8. Renato F, Paolo V, Girolamo M, et al. Malignant retroperitoneal teratoma: Case report and literature review. Acta Urol Belg 1996; 64: 49-54.

9. Ohno Y, Kanematsu T. An endodermal sinus tumor arising from a mature cystic teratoma in the retroperitoneum in a child: Is a mature teratoma a premalignant condition? Hum Pathol 1998; 29: 1167-9.

10. Luo CC, Huang CS, Chu SM, Chao HC, Yang CP, Hseueh C. Retroperitoneal teratomas in infancy and childhood. Pediatr Surg Int 2005; 21: 536-40.

11. Choyke PL, Hayes WS, Sesterhenn IA. Primary extragonadal germ cell tumors of the retroperitoneum: differentiation of primary and secondary tumors. Radiographics 1993; 13: 1365-75.

12. Berry CL, Keeling J, Hilton C. Teratomata in infancy and childhood: A review of 91 cases. J Pathol 1969; 98: 241-252.

13. Carney JA, Thompson DP. Johnson CL. Lynn HB. Teratomas in children: Clinical and pathologic aspects. J Pediutr Surg 1972; 7: 271-82.

14. Marsden HB, Birch JM, Swindell R. Germ cell tumor of childhood: A review of 137 cases. J Clin Puthol 1981; 34: 879-83.

15. Agarwal BR, Patel M, Shah BN, Currimbhoy Z, Waingankar VS, Meisheri I, Kapur VK, Murthy AK. Endodermal sinus tumor: report of 12 cases. Indian Pediatr 1993; 30: 1321-6.

16. Hirayama Y, Kubota M, Imamura M, et al. A 2-year-old boy with a stage III yolk sac tumor occurring in an intra-abdominal retained testis. J Pediatr Surg 2009; 44: 2395-8.

17. Lev MH, Blickman JG. Extragonadal yolk sac tumor: sonographic and CT findings. AJR Am J Roentgenol 1993; 160: 370-1.

18. Lack EE, Travis WD, Welch KJ. Retroperitoneal germ cell tumors in childhood. A clinical and pathologic study of 11 cases. Cancer 1985; 56: 602-8.

19. Scholz M, Zehender M, Thalmann GN, Borner M, Thöni H, Studer UE. Extragonadal retroperitoneal germ cell tumor: evidence of origin testis. Ann Oncol 2002; 13: 121-4.

\section{Address for correspondence}

\section{Prof. Elli Murat}

Deparment of Pediatric Oncology Atakum/Samsun

Medicine Faculty

Ondokuz May s University

55139 Samsun, Turkey

e-mail: ellimurat@yahoo.com 